\title{
Evaluation and monitoring instrument: Client Evaluation of Self and Treatment
}

\section{Instrumento de avaliação e monitoramento: Client Evaluation of Self and Treatment}

\author{
Andreia de Moura ${ }^{1}$, Lígia Ferros ${ }^{2}$, Jorge Negreiros 3 \\ 1 Foundation for Science and Technology (FCT) (SFRH/BD/67113/2009), Faculty of Psychology and Education Science, University of Porto, Portugal. \\ 2 Institute of Psychology and Education Science, University Lusíada of Porto, Portugal. \\ 3 Faculty of Psychology and Education Science, University of Porto, Portugal.
}

Received: 6/21/2012- Accepted: 3/5/2013

Moura A, et al. / Rev Psiq Clín. 2013;40(4):165-6

\section{Dear Editor,}

Substance use and dependence remains a very serious health problem in developed countries. Therefore, evaluating and monitoring the efficacy of substance use treatment programmes has become a matter of growing concern. The use of brief and multi-dimensional instruments has been indicated as a possible solution ${ }^{1,2}$, since it allows a swift diagnosis of the individual and the services one was provided with, enabling the adjustment of the interventions according to the users' needs and comorbidities ${ }^{3-9}$. In order to evaluate and monitoring the efficacy of substance use treatments, a pilot study was undertaken for the Portuguese population based on a brief multi-dimensional instrument, the Texas Christian University - Client Evaluation of Self and Treatment - TCU - CEST 1 . The choice of this instrument was based upon four basic criteria: (a) adequate values of validity and fidelity found in the original instrument ${ }^{1}$, (b) applicability to a variety of dependence treatment programmes, (c) wide evaluation of the efficacy indicators diversity, and (d) confirmed utility in the clinical practice ${ }^{1,10}$. The instrument is composed of a total of 130 items that are grouped into four dimensions: (a) motivation for treatment, (b) psychological functioning, (c) social functioning, and (d) therapeutic process ${ }^{1,4,10}$. At first, the translation and back-translation were done by a bilingual specialist. This was followed by the spoken reflection with 30 users aimed at evaluating the items' understanding and adequacy and individual pilot interviews with 8 professionals of 4 specialties ( 2 social work assistants, 3 psychologists, 2 psychiatrists and 1 nurse). As a second step, the questionnaire was administered to a convenience sample of 120 users (75\% in a programme of opioid replacement therapy with methadone), in the Centre of Integrated Responses - west Oporto, composed of 114 men (95\%) and 6 women (5\%), between the ages of 19 and 56 $(M=38)$, and $90 \%$ of Portuguese nationality. All the interviewees could speak and understand Portuguese. The results suggest that the majority of the subscales present regular values of global adjustment and acceptable values of internal consistency, as can be seen in the dimensions Therapeutic process $(\mathrm{GFI}=.946-1.0, \mathrm{AGFI}=.903-1.0$, CFI $=.967-1.0$, RMSEA $=.000-.072, \alpha=.684-.888)$ and Psychological functioning (with the exception of the Self-efficacy subscale) (GFI = $.963-.991, \mathrm{AGFI}=.926-.961, \mathrm{CFI}=.955-1.0, \mathrm{RMSEA}=.000-.055, \alpha$ $=.697-.746$ ). Unlike the results reported by Joe et al. (2002)1, some subscales present limitations: the dimension Motivation for treatment $(\mathrm{GFI}=.974-980, \mathrm{AGFI}=.916-.941, \mathrm{CFI}=.939-979$, RMSEA $=.028-.083, \alpha=.329-.655)$; and, in terms of internal consistency, the subscales Self-efficacy $(\alpha=.542)$, Risky behaviour $(\alpha=.665)$ and Social conscience $(\alpha=.406)$. The small size of the sample and its specificity $(75 \%$ in a programme of opioid replacement therapy with methadone) may have contributed to the reported results. As so, given the inadequacy of some items of the dimension Motivation for the treatment, we have suggested the elimination of this dimension in future applications of the TCU-CEST - Portuguese version ${ }^{2}$. The results of this study also underscore the need to revising the subscales Self-efficacy, Risky behaviour and Social conscience, as to achieve a closer cultural adaptation to the Portuguese context. Finally, further research should be undertaken in order to assess the validity of the instrument TCU-CEST, by examining its adequacy with samples of users dependent on other drugs and users in different treatment programmes. 
Table 1. Confirmatory factor analysis ${ }^{a}$ and internal consistencyb per subscale

\begin{tabular}{|c|c|c|c|c|c|c|c|}
\hline Scales & GFI & AGFI & $\mathrm{CFI}$ & RMSEA & PCLOSE & No. of items & Alpha \\
\hline \multicolumn{8}{|l|}{ Treatment motivation scales } \\
\hline A - Desire to get help & 0.980 & 0.941 & 0.975 & 0.044 & 0.454 & 5 & 0.560 \\
\hline B - Treatment readiness & 0.974 & 0.921 & 0.939 & 0.072 & 0.284 & 5 & 0.329 \\
\hline $\mathrm{C}$ - Treatment needs & 0.978 & 0.916 & 0.978 & 0.083 & 0.231 & 5 & 0.655 \\
\hline D - Pressures for treatment index & 0.976 & 0.938 & 0.979 & 0.028 & 0.572 & 6 & 0.378 \\
\hline \multicolumn{8}{|l|}{ Psychological functioning scales } \\
\hline E-Self-esteem & 0.989 & 0.961 & 1.000 & 0.000 & 0.806 & 6 & 0.726 \\
\hline F-Depression & 0.991 & 0.932 & 0.955 & 0.055 & 0.356 & 5 & 0.746 \\
\hline G-Anxiety & 0.963 & 0.927 & 0.981 & 0.040 & 0.541 & 7 & 0.697 \\
\hline $\mathrm{H}$ - Decision making & 0.966 & 0.926 & 0.985 & 0.039 & 0.545 & 8 & 0.718 \\
\hline I-Self-efficacy & 0.997 & 0.987 & 1.000 & 0.000 & 0.782 & 4 & 0.542 \\
\hline \multicolumn{8}{|l|}{ Social functioning scales } \\
\hline $\mathrm{J}$-Hostility & 0.965 & 0.907 & 0.963 & 0.072 & 0.265 & 6 & 0.728 \\
\hline $\mathrm{K}$ - Risk taking & 0.973 & 0.923 & 0.973 & 0.054 & 0.408 & 6 & 0.665 \\
\hline $\mathrm{L}-$ Social consciousness & 0.973 & 0.942 & 1.000 & 0.000 & 0.786 & 6 & 0.406 \\
\hline \multicolumn{8}{|l|}{ Therapeutic engagement domains } \\
\hline $\mathrm{M}$ - Treatment satisfaction & 0.968 & 0.903 & 0.967 & 0.072 & 0.271 & 6 & 0.698 \\
\hline $\mathrm{N}-$ Counseling rapport & 0.946 & 0.904 & 0.995 & 0.022 & 0.787 & 11 & 0.845 \\
\hline 0 - Treatment participation & 0.947 & 0.906 & 1.000 & 0.000 & 0.923 & 11 & 0.796 \\
\hline $\mathrm{P}$-Peer support & 1.000 & 1.000 & 1.000 & 0.000 & 0.993 & 3 & 0.684 \\
\hline 0 - Social support & 0.967 & 0.934 & 1.000 & 0.004 & 0.743 & 8 & 0.888 \\
\hline
\end{tabular}

a Values of global adjustment after the elimination of problematic items.

b Values of Cronbach's alpha with the exclusion of items. being selected the most consistent model.

\section{References}

1. Joe GW, Broome KM, Rowan-Szal GA, Simpson DD. Measuring patient attributes and engagement in treatment. J Subst Abuse Treat. 2002;22:183-96.

2. Moura A. Avaliação e monitorização do tratamento na toxicodependência: um estudo piloto do Texas Christian University (TCU) Client Evaluation of Self and Treatment (CEST) [Evaluation and monitoring of treatment in drug addiction: a pilot study of Texas Christian University (TCU) Client Evaluation of Self and Treatment (CEST)]. Porto: Faculdade de Psicologia e de Ciências de Educação da Universidade do Porto; 2008.

3. Goor I, Garretsen H. Evaluation of the programme and future recommendations. J Subst Use. 2005;10(2-3):164-8.

4. Machado PP, Klein JM, Farate C. Monitorização dos resultados terapêuticos no contexto de tratamento das toxicodependências [Monitoring of therapeutic results in the context of drug treatment]. Psicologia: Teoria, Investigação e Prática. 2005;1:019-029.

5. Fontes A, Figlie NB, Laranjeira R. O comportamento de beber entre dependentes de álcool: estudo de seguimento [Drinking be- haviour between alcohol users: a follow-up study]. Rev Psiq Clín. 2006;33(6):304-12.

6. Negreiros J. Psychological drug research: current themes and future developments. Council of Europe Publishing; 2006.

7. Simpson DD, Flynn PM. Moving innovations into treatment: a stage-based approach to program change. J Subst Abuse Treat. 2007;33(2):111-20.

8. Marsden V. Comorbidades entre dependência química, distimia, HIV e HCV: relato de caso [Comorbidity between addiction, dysthymia, HIV and HCV: case report]. Rev Psiq Clín. 2009;36(1):31-3.

9. Donovan DM, Bigelow GE, Brigham GS, Carroll KM, Cohen AJ, Gardin JG, et al. Primary outcome indices in illicit drug dependence treatment research: systematic approach to selection and measurement of drug use end-points in clinical trials. Addiction. 2012;107(4):694-708 doi:10.1111/j.1360-0443.2011.03473.x.

10. Simpson DD. A conceptual framework for drug treatment process and outcomes. J Subst Abuse Treat. 2004;27:99-121. doi:10.1016/j. jsat.2004.06.001. 